\title{
Acta Médica Peruana: retomando el camino hacia la indización
}

\section{Acta Medica Peruana: back on the road for being included in Medline and Scopus}

Recibido: 02/05/2016 Aprobado: 04/05/2016

Citar como:

Palacios-Celi M. Acta Médica Peruana: retomando el camino hacia la indización. Acta Med Peru. 2016;33(1):5-6
Miguel Palacios-Celi ${ }^{1}$

1 Decanato Nacional, Colegio Médico del Perú. Lima, Perú.
En éste primer número de nuestra revista Acta Médica Peruana (AMP) correspondiente al año 2016, el nuevo Comité Ejecutivo Nacional (periodo 2016-2017) del Colegio Médico del Perú (CMP) asume un reto de interés de todos los médicos peruanos, llevar a AMP al nivel que requerido para su pronta indización a Medline y Scopus.

Lamentablemente al asumir esta nueva gestión del CMP, encontramos en una situación crítica a AMP, ninguno de los cuatro números correspondientes al año 2015 estaban disponibles en forma electrónica, ni en la web de la revista ni en las bases de datos donde estaba indizada. Inclusive sólo los dos primeros números habían sido impresos y los autores se han quejado de una falta de comunicación fluida o en el proceso editorial (ver fe de erratas de este número). Esta falta de disponibilidad de contenidos en SciELO Perú puso en riesgo a AMP de ser retirada de esta importante base de datos científica.

Ante la problemática encontrada, el Comité Ejecutivo Nacional del Colegio Médico del Perú nombró al nuevo Comité Editorial de Emergencia de la revista Acta Médica Peruana, designando al Dr. Alberto Zolezzi Francis, como nuevo Director de AMP y al Dr. Percy Mayta-Tristán como Editor, ambos con amplia experiencia editorial, el primero con una experiencia de 21 años en la Revista de Gastroenterología del Perú y responsable de su reindexación a Medline [1] y el segundo con 11 años de experiencia en la Revista Peruana de Medicina Experimental y Salud Pública quien ejecutó el proceso de indización a Scopus y Medline [2]; quienes junto a Edén Galán-Rodas, Cristian Díaz-Vélez [3] y José Aguilar como miembros del Comité Editor lograron en el primer mes, regularizar la presencia de AMP en SciELO Perú y otras bases de datos, evitando así que sea retirada de esas bases de datos.

Por otro lado, es necesario informar que no se recibió de parte de la gestión anterior del Fondo Editorial del CMP ningún documento oficial de trasferencia del estado del Fondo Editorial Comunicacional así como de AMP, situación que coincide con la grave crisis financiera y económica del CMP, que afecta la marcha de nuestra institución en todos sus niveles. En ese aspecto, es posible que muchos autores no hayan tenido una respuesta de sus envíos durante todo el 2015, se tuvo que crear un nuevo correo de la revista, y con quienes se pudo tener contacto se ofrecieron las disculpas del caso y el procesamiento de sus artículos. Queremos aprovechar este espacio para disculparnos con todos los autores y revisores que en la gestión anterior de AMP sintieron que no se realizó el proceso como es debido.

La presente gestión ha conformado el nuevo Fondo Editorial Comunicacional (FEC) al cual pertenece AMP, con destacados médicos de la orden, tales como: Dr. Ciro Maguiña Vargas (Presidente del FEC) e integrado por los Drs. Alberto Zolezzi Francis, Oscar Pamo Reyna, Aldo Vivar Mendoza, Jorge González Mendoza, José Pacheco Romero y Gustavo Gonzales Rengifo. 
El relanzamiento de Acta Médica Peruana, requiere hoy más que nunca del apoyo de todos los médicos del Perú, particularmente de los nuevos Decanos de los 27 Consejos Regionales, de las Sociedades Medicas Científicas, para que realicen la difusión correspondiente para que sus asociados envíen sus importantes trabajos científicos, así como de todas las escuelas de medicina para que sus profesores y estudiantes de posgrado y pregrado envíen sus contribuciones, de tal manera que AMP tenga la calidad que todos los médicos peruanos merecemos.

La meta trazada es ambiciosa, pero necesaria, AMP debe postularse a Scopus y Medline con la cantidad y calidad de artículos requerida. Brindaremos un proceso editorial rápido pero con la rigurosidad de la revisión por pares que caracteriza a una revista científica. Así mismo, aseguraremos la independencia editorial para que las futuras gestiones del CMP mantengan un equipo editorial con experiencia, calidad y disposición para cumplir la tarea encomendada.

Finalmente, en este número se presenta información de relevancia para la salud pública vinculada con el virus Zika a través de una revisión sobre los aspectos que todo médico debe saber [4], así como una revisión de la situación en Centroamérica [5] y un informe sobre Colombia [6].

\section{REFERENCIAS BIBLIOGRÁFICAS}

1. Zolezzi A. XXX aniversario de la Revista de Gastroenterología del Perú. Rev Gastroenterol Peru. 2010;30(3):200-1.

2. Burstein Z, Mayta Tristán P. La Revista Peruana de Medicina Experimental y Salud Pública ahora indizada en MEDLINE/Index Medicus. Rev Peru Med Exp Salud Publica. 2010;27(3):312-4.

3. Diaz-Velez C. Visibilidad de la Revista del Cuerpo Médico del Hospital Nacional Almanzor Aguinaga Asenjo. Rev Cuerpo Med HNAAA. 2012;5(3):6.

4. Maguiña C, Galán-Rodas E. El virus Zika: una revisión de literatura. Acta Med Peru. 2016;33(1):35-41.

5. Nuñez E, Vásquez M, Beltrán-Luque B, Padgett D. Virus Zika en Centroamérica y sus complicaciones. Acta Med Peru. 2016;33(1):42-49.

6. Rodriguez-Morales AJ, Patiño-Valencia S, Villamil-Gómez WE, Alvarado-Socarras JA, Jimenez-Carrizales CE. Situación del Zika en Colombia: experiencia de los miembros de la Red Colombiana de Colaboración en Zika (RECOLZIKA). Acta Med Peru. 2016;33(1):79-81.

\title{
Las ediciones anteriores de Acta Médica Peruana están disponibles en:
}

\author{
www.scielo.org.pe
}

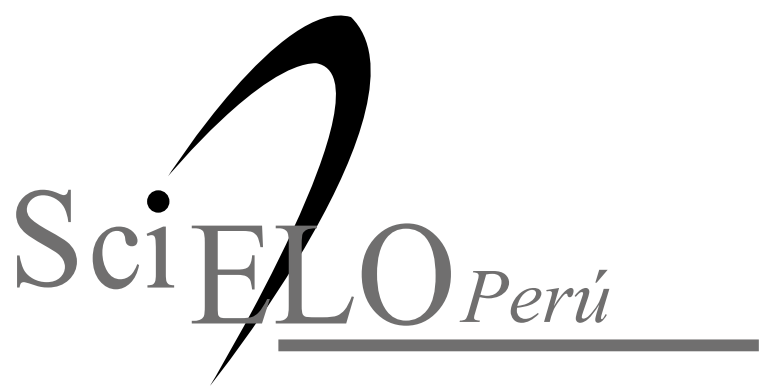

